\title{
ELISA Serology for Antibodies Against Chlamydia trachomatis in Crohn's Disease
}

\author{
Herbert J. Van Kruiningen ${ }^{\mathrm{a}, \mathrm{f}}$, Zeinab Helal ${ }^{\mathrm{a}, \mathrm{b}}$, Ariane Leroyer ${ }^{\mathrm{c}}$, Antonio Garmendia ${ }^{\mathrm{a}}$, \\ Corrine Gower-Rousseau ${ }^{\mathrm{d}, \mathrm{e}}$
}

\begin{abstract}
Background: Recently we reported IgA anti-Chlamydia antibodies in patients with Crohn's disease (CD), in particular in four patients from a single family of six with $\mathrm{CD}$.

Methods: We studied sera from four cohorts from the north of France. These were identified as: EPIMAD ( 80 pediatric onset CD and 20 pediatric onset ulcerative colitis), MINOTOR (148 adult onset sporadic $\mathrm{CD}$ and 50 adult onset ulcerative colitis), Grande Famillies (50) and matched controls for the Grande Famillies cohort (49). Sera were tested using commercial anti-Chlamydia trachomatis (LGV2:434) IgG and IgA human enzyme-linked immunosorbent assay (ELISA) kits. Cutoff for positivity was 11.0 standard units.
\end{abstract}

Results: Patients with sporadic CD, unaffected first degree relatives from multiplex families and ulcerative colitis patients had no greater serologic reactivity than controls. However, multiplex families' patients had twice as many positives as the other groups: for IgG $20 \%$ vs. $8 \%$; for $\operatorname{IgA} 20 \%$ vs. $10 \%$.

Conclusions: Though not attaining statistical significance, the data showed that familial CD patients had greater exposure to $C$. trachomatis than sporadic $\mathrm{CD}$ patients, supporting our earlier results from one family from the north of France. More specific serologic tests based on outer membrane proteins will need to be employed against the various Chlamydia species with zoonotic potential.

Manuscript submitted October 14, 2017, accepted October 27, 2017

${ }^{\text {aDepartment }}$ of Pathobiology and Veterinary Science, University of Connecticut, Storrs, CT, USA

${ }^{b}$ Department of Microbiology and Immunology Faculty of Pharmacy, AlAzhar University, Cairo, Egypt

'EA4483 - IMPECS - IMPact of Environmental ChemicalS on Human Health, Faculte de Medecine, Lille 2 University, France

dInserm, UMR 995, LIRIC, Team 5 "Epidemiology of Inflammatory Bowel Disease: From Epidemiology to Functional Analysis", Faculte de Medecine, Lille 2 University, France

eDepartment of Public Health, Epidemiology and Economic Health, Registre Epimad, Maison Regionale de la Recherche Clinique, Centre Hospitalier Universitaire Regional, Lille, France

${ }^{f}$ Corresponding Author: Herbert J. Van Kruiningen, Department of Pathobiology, University of Connecticut, 61 North Eagleville Road, U3089, Storrs, CT 06269-3089, USA. Email: herbert.vankruiningen@uconn.edu

doi: https://doi.org/10.14740/gr922w
Keywords: Crohn's disease; Regional enteritis; Chlamydia; Serology; ELISA

\section{Introduction}

In the recent past, we established that obstructed lymphatics represent the fundamental intestinal injury in the pathogenesis of Crohn's disease (CD) [1,2]. Searching for microbes that might damage lymphatic endothelium and in particular the endothelium of intestinal lymphatics, we discovered the importance of an infectious pig model of $\mathrm{CD}$, in animals inoculated with Chlamydia suis [3]. As a consequence, evidence for Chlamydia in the resected tissues of patients and antibodies against this microorganism were sought [4].

Employing commercial enzyme-linked immunosorbent assay (ELISA) kits for Chlamydia trachomatis, serology for anti-Chlamydia IgG revealed two positive values in 24 patients, versus one positive among 15 controls, while serology for anti-Chlamydia IgA revealed four positives among the 24 patients, and one positive in 15 controls [4]. One patient and one control had both elevated IgG and IgA titers. The four patients with elevated $\operatorname{IgA}$ titers were from a single family of six, all of whom had CD [4]. In an attempt to test the importance of positive serology, we investigated 323 sera from patients registered with an inflammatory bowel disease (IBD) center in northern France, as well as 74 control sera from the same region.

\section{Materials and Methods}

Patient's sera were obtained from three different studies: Epimad (100), Minotor (198), and Grande Famillies (50). Control sera (49) were obtained from families without inflammatory bowel diseases matched to the Grande Famillies, for size and number, gender, and ages in the second generation. The Epimad cohort consisted of 80 patients with CD and 20 with ulcerative colitis, all of whom were pediatric onset patients, defined by a diagnosis of IBD before the age of 17 . The Minotor comprised 148 patients with sporadic $\mathrm{CD}$, and 50 with ulcerative colitis, all from the tertiary care center at Centre Hospitalier Regional Universitaire de Lille. In the Grande Famillies cohort, there were 25 patients with $\mathrm{CD}$ and 25 unaffected first 
Table 1. ELISA Serology vs. Chlamydia trachomatis

\begin{tabular}{|c|c|c|c|c|c|c|c|}
\hline \multirow[b]{2}{*}{ Sample group } & \multicolumn{3}{|c|}{ Families studies } & \multicolumn{4}{|c|}{ Sporadic cases } \\
\hline & $\begin{array}{l}\text { Healthy controls } \\
\text { for multiplex } \\
\text { families }(n=49)\end{array}$ & $\begin{array}{l}\text { Healthy relatives*, } \\
\text { in multiplex } \\
\text { families }(n=25)\end{array}$ & $\begin{array}{l}\text { CD in multi- } \\
\text { plex families } \\
(n=25)\end{array}$ & $\begin{array}{l}\text { CD pedi- } \\
\text { atric-onset } \\
(n=80)\end{array}$ & $\begin{array}{l}\text { UC pedi- } \\
\text { atric-onset } \\
(n=20)\end{array}$ & $\begin{array}{l}\text { CD adult- } \\
\text { onset }(\mathrm{n} \\
=148)\end{array}$ & $\begin{array}{l}\text { UC adult- } \\
\text { onset ( } \mathrm{n} \\
=50 \text { ) }\end{array}$ \\
\hline IgG positives & $4(8 \%)$ & $2(8 \%)$ & $5(20 \%)$ & $1(1 \%)$ & $2(10 \%)$ & $14(9 \%)$ & $5(10 \%)$ \\
\hline IgA positives & $5(10 \%)$ & $2(8 \%)$ & $5(20 \%)$ & $8(10 \%)$ & $1(5 \%)$ & $15(10 \%)$ & $3(6 \%)$ \\
\hline $\begin{array}{l}\text { Either IgG or IgA } \\
\text { positive or both }\end{array}$ & $7(14 \%)$ & $3(12 \%)$ & $6(24 \%)$ & $9(11 \%)$ & $3(15 \%)$ & $28(19 \%)$ & $7(14 \%)$ \\
\hline Male \% & $37 \%$ & $44 \%$ & $40 \%$ & $45 \%$ & $35 \%$ & $43 \%$ & $46 \%$ \\
\hline Age median (min - max) & $39(16-78)$ & $41(17-78)$ & $35(17-79)$ & $24(16-37)$ & $26(20-35)$ & $31(17-65)$ & $40(18-70)$ \\
\hline
\end{tabular}

CD: Crohn's disease; UC: ulcerative colitis. *Healthy first degree relatives of CD patients in multiplex families.

degree relatives, from 17 families. All the patients and controls were from northern France. Sera were frozen at $-80^{\circ} \mathrm{C}$ within the registry and later transported by air carrier to the University of Connecticut.

Sera were tested using anti-C. trachomatis (LGV 2:434) IgG human ELISA kits, and anti-C. trachomatis (LGV 2:434) IgA human ELISA kits (Abcam, Cambridge, MA), according to the manufactures instructions. Briefly, all materials were equilibrated at room temperature prior to use. For initial detection of specific antibodies, serum samples were diluted 1 to 100 with sample diluent as indicated in the manufacturer's instructions. Limited cross reactivity data are available for the kits used. Cutoff for positivity was 11.0 standard units.

Statistical analysis used Chi-square or Fisher's exact tests for categorical data, and Kruskal-Wallis tests for quantitative data. Effect of age, sex and disease status on positive $C$. trachomatis serology was tested on IgG positivity, IgA positivity and positivity of either IgA or IgG. Additional comparisons were done within the families' studies, among controls, healthy relatives and $\mathrm{CD}$ patients; within sporadic cases, between $\mathrm{CD}$ and ulcerative colitis (UC) patients.
The study was conducted in accord with University of Connecticut IRB approval, protocol HO8-128.

\section{Results}

Results are summarized in Table 1. Employing these ELISA tests, patients with sporadic CD, unaffected first degree relatives from multiplex families, and ulcerative colitis patients had no greater serologic reactivity than controls.

On the other hand, multiplex families had twice as many positives, i.e., above the cutoff, as the other groups: for IgG, $\mathrm{CD}$ in Grande Famillies vs. controls $(20 \%$ versus $8 \%, \mathrm{P}=$ 0.22 ); for IgA, CD in Grande Famillies vs. controls (20\% versus $10 \%, \mathrm{P}=0.29$ ) (Fig. 1 ).

Positive IgG and IgA/IgG serologies increased with age (P $<0.01$ and $\mathrm{P}=0.01$, respectively), but not $\operatorname{IgA}(\mathrm{P}=0.10)$. Positive IgG serology was more often observed in females than in males $(\mathrm{P}=0.06)$, but not for $\operatorname{IgA}$ or $\operatorname{IgA} / \operatorname{IgG}$.

No significant difference was observed among the three groups of subjects within the families' studies, and between

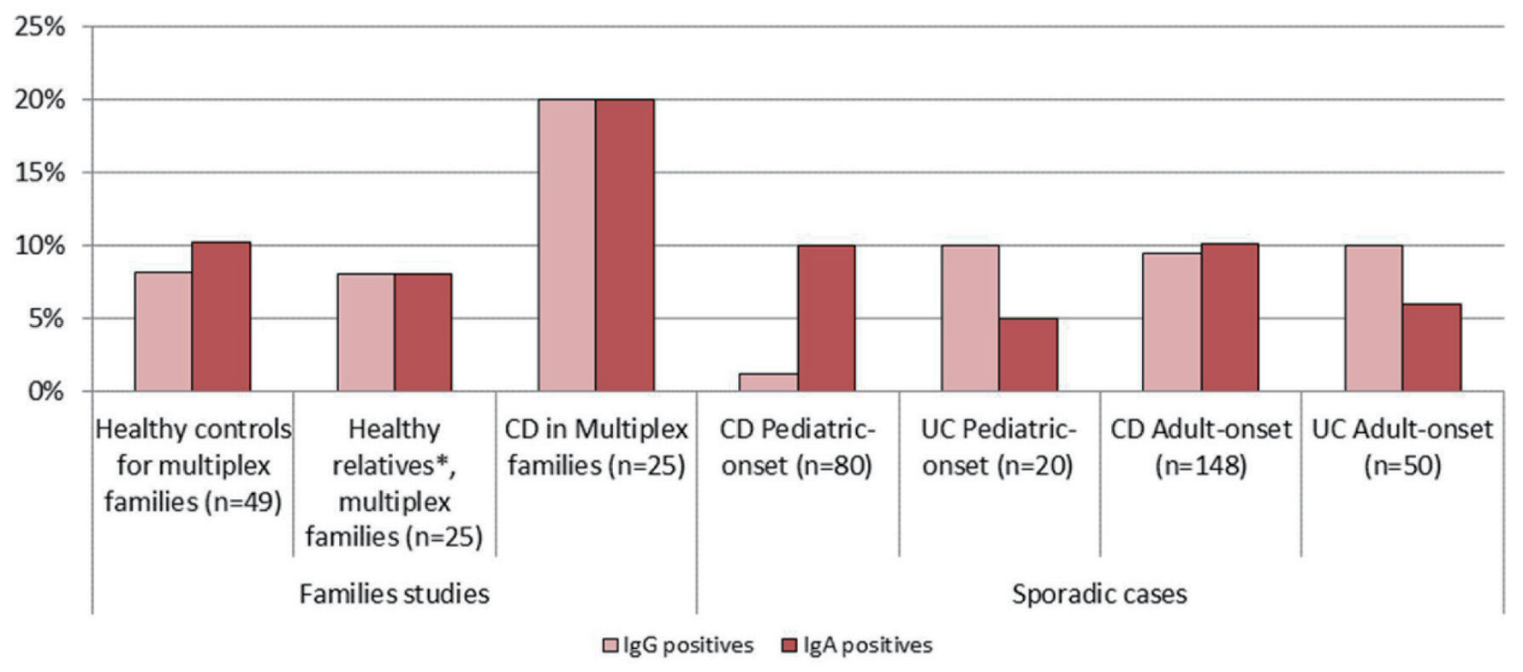

Figure 1. Positive serology vs. Chlamydia trachomatis in patients and control groups. *Healthy first degree relatives of CD patients in multiplex families 
Table 2. Previously Reported Anti-Chlamydia Antibodies in Crohn's Disease

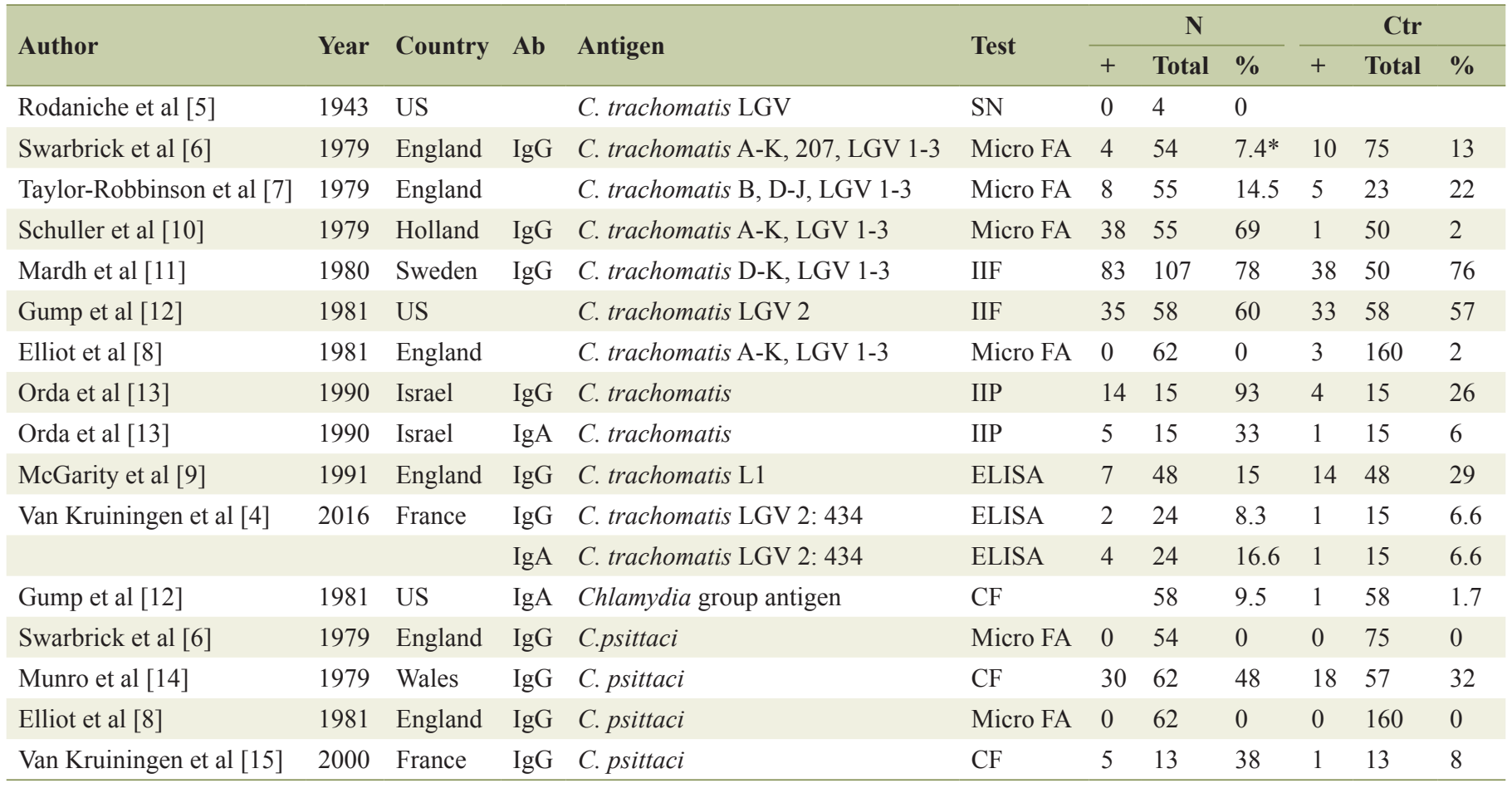

Ab: antibody; Ctr: control; ELISA: enzyme-linked immunosorbent assay. ${ }^{*} 7.4 \%$ were positive to serovars A-K or 207.

$\mathrm{CD}$ and UC patients within sporadic cases. Nonetheless, positive IgA serology was $10 \%(23 / 228)$ for sporadic CD patients and $6 \%(4 / 70)$ for sporadic UC patients $(\mathrm{P}=0.26)$.

\section{Discussion}

At first glance, our data (Table 2 [4-15]) appear to show no serologic relationship between $C$. trachomatis and CD. This finding, of a lack of or little antibody response in CD patients, agrees with Rodaniche et al [5], Swarbrick et al [6], Taylor-Robinson et al [7], Elliot et al [8] and McGarity et al [9] of previous studies done by other methods, and it disagrees with Schuller et al [10], Mardh et al [11], Gump et al [12] and Orda et al [13]. This test would not serve to identify patients with CD.

On the other hand, though not attaining statistical significance, the data appear to show that familial CD patients have had greater exposure to Chlamydia antigen than sporadic CD patients, which supports our earlier results with one family from the north of France (in the latter instance, in IgA levels) [4]. If the difference is real, what possible reasons might explain the increased number of positives in familial disease? Was there important genetic susceptibility, or, was there a greater level of exposure to Chlamydia within family settings? Were the Grande Famillies exposed to a different, and crossreacting, Chlamydia species? Or is there a geographic reason for the greater proportion of positives? One wonders how our data would compare to sporadic and familial disease data from the south of France.

The test employed was designed to discriminate patients exposed to C. trachomatis lymphogranuloma venereum (LGV) serotypes. Based on reactivity to lipopolysaccharide, sera with antibodies to any species of Chlamydia should react [16]. During the development of the Abcam serologic test, it was established that cross-reactivity with C. pneumoniae does not occur. Sera from 14 patients who had recovered from infection with C. pneumoniae all failed to react in the Abcam test. Cross-reactivities to other Chlamydia, such as those harbored in farm species (C. psittaci, C. abortus, C. suis, and C. pecorum), and to Gram-negative bacteria, have never been tested.

From experimental work in monkeys, it is known that different antibody responses occur to $C$. trachomatis LGV serotypes and E-serotypes [17]. Had the Abcam ELISA test, with its defined cutoff, been applied to the experimental monkeys, those with LGV proctitis would have been regarded as positive, whereas those infected with serovar E would have fallen below detection. Extent of disease in an affected organ is of additional concern; women with acute salpingitis have been shown to have $\mathrm{IgG}$ responses (to serotypes $\mathrm{D}-\mathrm{K}$ ) proportional to severity of disease [18]. Antibodies have a finite life, thus duration of disease from onset to the time of testing (very variable and often prolonged in CD) must influence titers against any putative organism. And, the use of antibiotics early in the illness has the potential to abort antibody responses. Patients with CD report greater use of antibiotics during childhood and adolescent years than control subjects [19]. These factors ameliorate conclusions from this study.

There is concordance between the enteric lymphatic pathology of CD and that of the Chlamydia suis-infected pig [3]. The various species and serotypes of Chlamydia that occur 
in disease states [16, 20-22], plus the variable production of antibody, in target tissues, e.g., the lung, conjunctiva, uterus, placenta, urethra, joints or gastrointestinal tract, suggest that more specific serologic tests, based on outer membrane proteins might yield better results. All of the Chlamydia species of animal origin have zoonotic potential [23-39]. We continue to hold the possibility that one of them is responsible for CD.

\section{Acknowledgments}

Grateful thanks are extended for the blood samples: Epimad Registry; Lille, Amiens \& Rouen University Hospitals; European Charity DigestScience Foundation; Programme Hospitalier de Recherche Clinique; and the Association Francois Aupetit. Thanks are extended to Dr. Karl Guillard at the University of Connecticut for help with Excel data analyses.

\section{Conflict of Interest}

The authors declare no conflict of interest.

\section{Financial Support}

The research was funded by the UCONN Office of the Vice President for Research.

\section{References}

1. Sura R, Colombel JF, Van Kruiningen HJ. Lymphatics, tertiary lymphoid organs and the granulomas of Crohn's disease: an immunohistochemical study. Aliment Pharmacol Ther. 2011;33(8):930-939.

2. Van Kruiningen HJ, Hayes AW, Colombel JF. Granulomas obstruct lymphatics in all layers of the intestine in Crohn's disease. APMIS. 2014;122(11):1125-1129.

3. Van Kruiningen HJ. An infectious pig model of Crohn's disease. Inflamm Bowel Dis. 2016;22(9):2106-2111.

4. Van Kruiningen HJ, Hayes A, Garmendia AE, Cui J, de Abreu FB, Tsongalis GJ, et al. Evidence for chlamydia in Crohn's disease. International Journal of Digestive Diseases. 2016;2:1-7.

5. Rodaniche E, Kirsner JB, Palmer W. The relationship between lymphogranuloma venereum and regional enteritis: An etiologic study of 4 cases with negative results. Gastroenterology. 1943;1:687-689.

6. Swarbrick ET, Kingham JG, Price HL, Blackshaw AJ, Griffiths PD, Darougar S, Buckell NA. Chlamydia, cytomegalovirus, and Yersinia in inflammatory bowel disease. Lancet. 1979;2(8132):11-12.

7. Taylor-Robinson D, O'Morain CA, Thomas BJ, Levi AJ. Low frequency of chlamydial antibodies in patients with Crohn's disease and ulcerative colitis. Lancet. 1979;1(8127):1162-1163.

8. Elliott PR, Forsey T, Darougar S, Treharne JD, Lennard-
Jones JE. Chlamydiae and inflammatory bowel disease. Gut. 1981;22(1):25-27.

9. McGarity BH, Robertson DA, Clarke IN, Wright R. Deoxyribonucleic acid amplification and hybridisation in Crohn's disease using a chlamydial plasmid probe. Gut. 1991;32(9):1011-1015.

10. Schuller JL, Piket-van Ulsen J, Veeken IV, Michel MF, Stolz E. Antibodies against Chlamydia of lymphogranuloma-venereum type in Crohn's disease. Lancet. 1979;1(8106):19-20.

11. Mardh PA, Ursing B, Sandgren E. Lack of evidence for an association between infection with Chlamydia trachomatis and Crohn's disease, as indicated by micro-immunofluorescence antibody tests. Acta Pathol Microbiol Scand B. 1980;88(1):57-59.

12. Gump D, Caul E, Eade O, Greenberg H, Kapikian A, MacPherson B, Mitchell P, et al. Lymphocytotoxic and microbial antibodies in Crohn's disease and matched controls. Antonie Van Leeuwenhoek. 1981;47(5):455-464.

13. Orda R, Samra Z, Levy Y, Shperber Y, Scapa E. Chlamydia trachomatis and inflammatory bowel disease--a coincidence? J R Soc Med. 1990;83(1):15-17.

14. Munro J, Mayberry JF, Matthews N, Rhodes J. Chlamydia and Crohn's disease. Lancet. 1979;2(8132):45-46.

15. Van Kruiningen HJ, Mayo DR, Vanopdenbosch E, Gower-Rousseau C, Cortot A, Colombel JF. Virus serology in familial Crohn disease. Scand J Gastroenterol. 2000;35(4):403-407.

16. Schautteet K, Vanrompay D. Chlamydiaceae infections in pig. Vet Res. 2011;42:29-38.

17. Quinn TC, Taylor HR, Schachter J. Experimental proctitis due to rectal infection with Chlamydia trachomatis in nonhuman primates. J Infect Dis. 1986;154(5):833-841.

18. Treharne JD, Ripa KT, Mardh PA, Svensson L, Westrom L, Darougar S. Antibodies to Chlamydia trachomatis in acute salpingitis. Br J Vener Dis. 1979;55(1):26-29.

19. Ungaro R, Bernstein CN, Gearry R, Hviid A, Kolho KL, Kronman MP, Shaw S, et al. Antibiotics associated with increased risk of new-onset Crohn's disease but not ulcerative colitis: a meta-analysis. Am J Gastroenterol. 2014;109(11):1728-1738

20. Shewen PE. Chlamydial infection in animals: a review. Can Vet J. 1980;21(1):2-11.

21. Bachmann NL, Polkinghorne A, Timms P. Chlamydia genomics: providing novel insights into chlamydial biology. Trends Microbiol. 2014;22(8):464-472.

22. Knittler MR, Berndt A, Bocker S, Dutow P, Hanel F, Heuer D, Kagebein D, et al. Chlamydia psittaci: new insights into genomic diversity, clinical pathology, host-pathogen interaction and anti-bacterial immunity. Int J Med Microbiol. 2014;304(7):877-893.

23. Dean D, Rothschild J, Ruettger A, Kandel RP, Sachse K. Zoonotic Chlamydiaceae species associated with trachoma, Nepal. Emerg Infect Dis. 2013;19(12):1948-1955.

24. De Puysseleyr K, De Puysseleyr L, Dhondt H, Geens T, Braeckman L, Morre SA, Cox E, et al. Evaluation of the presence and zoonotic transmission of Chlamydia suis in a pig slaughterhouse. BMC Infect Dis. 2014;14:560.

25. De Puysseleyr L, De Puysseleyr K, Braeckman L, Morre 
SA, Cox E, Vanrompay D. Assessment of chlamydia suis infection in pig farmers. Transbound Emerg Dis. 2017;64(3):826-833.

26. Hyde SR, Benirschke K. Gestational psittacosis: case report and literature review. Mod Pathol. 1997;10(6):602607.

27. Johnson FW, Matheson BA, Williams H, Laing AG, Jandial V, Davidson-Lamb R, Halliday GJ, et al. Abortion due to infection with Chlamydia psittaci in a sheep farmer's wife. Br Med J (Clin Res Ed). 1985;290(6468):592594.

28. Hadley KM, Carrington D, Frew CE, Gibson AA, Hislop WS. Ovine chlamydiosis in an abattoir worker. J Infect. 1992;25(Suppl 1):105-109.

29. Janssen MJ, van de Wetering K, Arabin B. Sepsis due to gestational psittacosis: A multidisciplinary approach within a perinatological center - review of reported cases. Int J Fertil Womens Med. 2006;51(1):17-20.

30. Beeckman DS, Vanrompay DC. Zoonotic Chlamydophila psittaci infections from a clinical perspective. Clin Microbiol Infect. 2009;15(1):11-17.

31. Van Droogenbroeck C, Beeckman DS, Verminnen K, Marien $\mathrm{M}$, Nauwynck H, Boesinghe Lde T, Vanrompay D. Simultaneous zoonotic transmission of Chlamydophila psittaci genotypes $\mathrm{D}, \mathrm{F}$ and $\mathrm{E} / \mathrm{B}$ to a veterinary scientist. Vet Microbiol. 2009;135(1-2):78-81.

32. Kalmar ID, Dicxk V, Dossche L, Vanrompay D. Zoonotic infection with Chlamydia psittaci at an avian refuge centre. Vet J. 2014;199(2):300-302.

33. Branley JM, Weston KM, England J, Dwyer DE, Sorrell TC. Clinical features of endemic community-acquired psittacosis. New Microbes New Infect. 2014;2(1):7-12.

34. Laroucau K, Vorimore F, Aaziz R, Berndt A, Schubert $\mathrm{E}$, Sachse K. Isolation of a new chlamydial agent from infected domestic poultry coincided with cases of atypical pneumonia among slaughterhouse workers in France. Infect Genet Evol. 2009;9(6):1240-1247.

35. Senn L, Greub G. Local newspaper as a diagnostic aid for psittacosis: a case report. Clin Infect Dis. 2008;46(12):1931-1932.

36. Hedberg K, White KE, Forfang JC, Korlath JA, Friendshuh KA, Hedberg CW, MacDonald KL, et al. An outbreak of psittacosis in Minnesota turkey industry workers: implications for modes of transmission and control. Am J Epidemiol. 1989;130(3):569-577.

37. Hinton DG, Shipley A, Galvin JW, Harkin JT, Brunton RA. Chlamydiosis in workers at a duck farm and processing plant. Aust Vet J. 1993;70(5):174-176.

38. Williams J, Tallis G, Dalton C, Ng S, Beaton S, Catton M, Elliott J, et al. Community outbreak of psittacosis in a rural Australian town. Lancet. 1998;351(9117):1697-1699.

39. Sachse K, Kuehlewind S, Ruettger A, Schubert E, Rohde G. More than classical Chlamydia psittaci in urban pigeons. Vet Microbiol. 2012;157(3-4):476-480. 